\title{
CECILIA Regional Climate Simulations for Future Climate: Analysis of Climate Change Signal
}

\author{
Michal Belda, ${ }^{1}$ Petr Skalák, ${ }^{2,3}$ Aleš Farda, ${ }^{2,3}$ Tomáš Halenka, ${ }^{1}$ \\ Michel Déqué, ${ }^{4}$ Gabriella Csima, ${ }^{5}$ Judit Bartholy, ${ }^{6}$ Csaba Torma, \\ Constanta Boroneant, ${ }^{8}$ Mihaela Caian, ${ }^{9}$ and Valery Spiridonov ${ }^{10}$ \\ ${ }^{1}$ Department of Meteorology and Environment Protection, Charles University in Prague, 18200 Prague, Czech Republic \\ ${ }^{2}$ Czech Hydrometeorological Institute, 14306 Prague, Czech Republic \\ ${ }^{3}$ Global Change Research Centre, Academy of Science of the Czech Republic, 60300 Brno, Czech Republic \\ ${ }^{4}$ National Centre for Meteorological Research, Météo France, 31057 Toulouse, France \\ ${ }^{5}$ Hungarian Meteorological Service, Budapest 1525, Hungary \\ ${ }^{6}$ Department of Meteorology, Eötvös Loránd University, Budapest 1518, Hungary \\ ${ }^{7}$ The Abdus Salam International Centre for Theoretical Physics, 34151 Trieste, Italy \\ ${ }^{8}$ Centre for Climate Change, Rovira i Virgili University, 43500 Tarragona, Spain \\ ${ }^{9}$ Rossby Centre, SMHI, 60176 Norrköping, Sweden \\ ${ }^{10}$ National Institute of Meteorology and Hydrology, 1784 Sofia, Bulgaria
}

Correspondence should be addressed to Michal Belda; michal.belda@mff.cuni.cz

Received 24 April 2014; Revised 8 August 2014; Accepted 11 August 2014

Academic Editor: Lian Xie

Copyright (C) 2015 Michal Belda et al. This is an open access article distributed under the Creative Commons Attribution License, which permits unrestricted use, distribution, and reproduction in any medium, provided the original work is properly cited.

\begin{abstract}
Regional climate models (RCMs) are important tools used for downscaling climate simulations from global scale models. In project CECILIA, two RCMs were used to provide climate change information for regions of Central and Eastern Europe. Models RegCM and ALADIN-Climate were employed in downscaling global simulations from ECHAM5 and ARPEGE-CLIMAT under IPCC A1B emission scenario in periods 2021-2050 and 2071-2100. Climate change signal present in these simulations is consistent with respective driving data, showing similar large-scale features: warming between 0 and $3^{\circ} \mathrm{C}$ in the first period and 2 and $5^{\circ} \mathrm{C}$ in the second period with the least warming in northwestern part of the domain increasing in the southeastern direction and small precipitation changes within range of +1 to $-1 \mathrm{~mm}$ /day. Regional features are amplified by the RCMs, more so in case of the ALADIN family of models.
\end{abstract}

\section{Introduction}

Regional climate models (RCMs) are tools that greatly enhance the usability of climate projections made by global climate models (GCMs) for studying climate and its change and impacts on a regional scale. Following the methodology of dynamical downscaling $[1,2]$, the outputs of GCMs can be used as driving fields for the nested RCMs running with higher resolution, allowing capturing the local features of the climate.

The Fifth Assessment Report of the Intergovernmental Panel on Climate Change [3] suggests changes in regional climate conditions in the 21st century over Central and Eastern
Europe (CEE). The Coupled Model Intercomparison Project Phase 5 (CMIP5) projections generally agree on warming in all seasons in Europe during the 21st century, while precipitation projections are more variable across different parts of Europe and seasons. CEE is a region where precipitation changes remain still uncertain. Even the findings of recent coordinated downscaling experiments in Europe, for example, projects PRUDENCE (Prediction of Regional Scenarios and Uncertainties for Defining European Climate Change Risks and Effects) [4] or ENSEMBLES (ENSEMBLE based predictions of climate changes and their impacts) [5] using RCM simulations of $25-50 \mathrm{~km}$ horizontal resolution, 
are consistent with the CMIP5 (Coupled Model Intercomparison Project Phase 5) projections and do not indicate any significant precipitation change in CEE. Although regional climate change amplitudes of temperature and precipitation follow global trends in Europe, they can be also affected by changes in the large-scale circulation and regional feedback processes [6]. Recent studies have also clearly identified importance of soil moisture changes and their impact on amplification of temperature extremes in Europe [7, 8]. Similar processes and meteorological extremes in general have strong consequences on local scale climate conditions and they can be only hardly captured by coarser resolution GCMs. Downscaling methods, both statistical and dynamical based on RCMs, may thus provide valuable information on climate change for assessing its regional impacts, detecting possible vulnerabilities, and adopting the relevant adaptation measures.

Climate change impacts and vulnerability assessment were the key objectives of two recent projects supported by European Commission's 6th Framework Programme: CECILIA (Central and Eastern Europe Climate Change Impact and Vulnerability Assessment, http://www.cecilia-eu. org/) [9-12] and CLAVIER (Climate Change and Variability: Impact on Central and Eastern Europe, http://www.clavier-eu.org/) [13]. The emphasis of both projects on CEE was not only due to uncertainties in the future climate evolution in this region. It also reflected the fact that CEE countries are relatively young and emerging market economies and thus potentially more vulnerable than developed Western Europe countries. The novel aspect of both projects was to deliver information on the climate change in the region of CEE by means of RCMs simulations at very high resolution of $10 \mathrm{~km}$ on a relatively small domain. Advantages of such model setup and ability of the CECILIA RCMs to capture the main features of the climate in the CEE in the past period 1961-1990 have been tested by several studies [14-16]. Skalák et al. [14] analysed the performance of CECILIA models driven by ERA-40 reanalysis ("perfectboundary" experiment). They concluded that the gain of using a high resolution RCM on a small domain (as in the CECILIA project) with respect to a lower resolution $(25 \mathrm{~km})$ over a larger domain (as in the ENSEMBLES project) is clear for air temperature but very limited for precipitation. The authors have also confirmed findings of previous studies, for instance, [17-19], validating influence of model resolution on simulated temperature and precipitation. Despite high systematic errors of RCMs in control climate simulations, those may not significantly affect the simulation of climate change and rule out RCMs from providing useful information on the future climate state. This study follows up on the paper by Skalák et al. [14] and presents the analysis of CECILIA climate change simulations in the region of CEE for 2021-2050 and 2071-2100 periods and compares the results of high resolution RCMs with their driving data.

\section{Modeling Setup}

The CECILIA modeling system consists of six individual simulations over various domains in Central and Eastern
Europe. Based on previous experience and experiment testing performed in the first stage of the project, six project partners (institutions) were involved in the Work Package 2 of the CECILIA project: Charles University in Prague, Czech Republic (CUNI), Czech Hydrometeorological Institute, Czech Republic (CHMI), Eötvös Loránd University, Hungary (ELU), Hungarian Meteorological Service, Hungary (OMSZ), National Meteorological Administration, Romania (NMA), and National Institute of Meteorology and Hydrology, Bulgaria (NIMH). The partners picked four RCMs for the climate studies, two versions of ALADIN-Climate [20] and two versions of RegCM3 [21], and made their choice of model and domain setup.

Two versions of ALADIN-Climate correspond to cycle 24 and cycle 28 of the ARPEGE/IFS code. Their physical parameterizations are different. While the original version of ALADIN-Climate (cycle 24) developed by Météo-France has a physical parameterization package derived directly from the one used in GCM ARPEGE-CLIMAT 4 [22], the other version, ALADIN-Climate/CZ (cycle 28), is based on the numerical weather prediction version of the ALADIN model in operational use at the Czech Hydrometeorological Institute in 2002 and 2003.

Two versions of RegCM3 differ in some aspects of the physical parameterizations: one in the original setting described by Pal et al. [21], named alpha for distinction, and the other, called beta, with applied changes into the largescale precipitation schemes. The modifications in the beta version were motivated by a large bias of precipitation found during sensitivity tests conducted with the RegCM3 alpha model over the Carpathian Basin and their justification can be found in Torma et al. $[23,24]$.

In order to produce scenarios of the 21st century with CECILIA high resolution RCMs, two types of boundary conditions were taken. ALADIN-Climate models were driven by the boundary condition of $50 \mathrm{~km}$ horizontal resolution coming from a "stretch mesh" version of ARPEGE-CLIMAT 4 GCM. This version of the GCM has a variable horizontal resolution being around $50 \mathrm{~km}$ over Southern Europe and decreasing to $\mathrm{ca} 300 \mathrm{~km}$ at the antipode. In case of RegCM3 models, a double nesting technique was applied. The CECILIA RegCM3 $10 \mathrm{~km}$ experiments were driven by another RegCM3 simulation of $25 \mathrm{~km}$ resolution that was forced by ECHAM5 GCM. The RegCM3 $25 \mathrm{~km}$ simulation was originally produced by the Abdus Salam International Centre for Theoretical Physics (ICTP) in the frame of the ENSEMBLES project. All CECILIA simulations undertaken are summarized in Table 1. Modeling domains of individual groups are illustrated in Figure 1.

CUNI was the only partner using the original version of RegCM3 alpha. The reason for not using the improved beta version was rather technical, since the modification was introduced after a big part of CUNI simulations had been carried out and it was not computationally feasible to repeat all the simulations within the scope of the project. The RegCM3 beta was however used by CUNI to prepare meteorological fields for coupling with chemical model CAMx for air quality studies in Work Package 7 of the CECILIA project (see Huszar et al. [11] for details). 
TABLE 1: CECILIA RCM-GCM setup.

\begin{tabular}{|c|c|c|c|c|c|}
\hline Partner & Regional model & Acronym & Horizontal resolution & $\begin{array}{c}\text { Domain size } \\
\text { [points and vertical } \\
\text { levels] }\end{array}$ & Boundary forcing (GCM) \\
\hline CUNI & RegCM3 alpha & $\mathrm{Ra}$ & $10 \mathrm{~km}$ & $184 \times 164 \times 23$ & RegCM3 @ 25 km (ECHAM5) \\
\hline CHMI & ALADIN-Climate/CZ & $\mathrm{Az}$ & $10 \mathrm{~km}$ & $160 \times 102 \times 43$ & ARPEGE-CLIMAT \\
\hline ELU & RegCM3 beta & $\mathrm{Rb}$ & $10 \mathrm{~km}$ & $120 \times 100 \times 18$ & RegCM3 @ 25 km (ECHAM5) \\
\hline NIMH & ALADIN-Climate & $\mathrm{A} 2$ & $10 \mathrm{~km}$ & $105 \times 80 \times 31$ & ARPEGE-CLIMAT \\
\hline NMA & RegCM3 beta & $\mathrm{Rb} 2$ & $10 \mathrm{~km}$ & $156 \times 102 \times 18$ & RegCM3 @ 25 km (ECHAM5) \\
\hline OMSZ & ALADIN-Climate & A & $10 \mathrm{~km}$ & $108 \times 72 \times 31$ & ARPEGE-CLIMAT \\
\hline
\end{tabular}

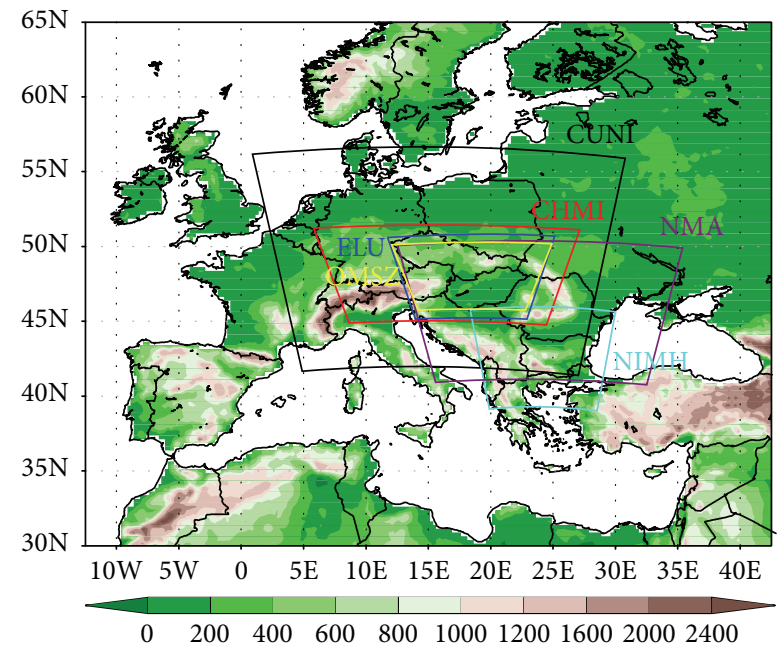

FIGURE 1: Integration domains of CECILIA simulations; shading: orography from E-OBS $(0.25 \mathrm{deg})$.

Four areas were identified for which the RCM simulations were performed: Central Europe (CHMI, CUNI), Carpathian Basin (OMSZ, ELU), Romania and Black Sea (NMA), and Bulgaria (NIMH). For the climate change projections, all partners were obliged to run the models for three time slices: 1961-1990 (present climate control run, CTL), 2021-2050 (near future run, NF), and 2071-2100 (far future run, FF). All future simulations were carried out using $\mathrm{CO}_{2}$ concentrations as described by the IPCC A1B scenario [25]. This scenario was the only possible choice due to the fact that the driving ENSEMBLES simulations were conducted for A1B scenario only.

\section{Climate Projections}

The following text analyses basic climate properties in the regional climate simulations of CECILIA models with focus on average precipitation and $2 \mathrm{~m}$ temperature. Main features of these variables in terms of yearly averages were analysed in three regions: composite of all model domains in CECILIA (i.e., in areas where at least one model simulation can be evaluated, used in Figures 2 and 9), Central European part of the domain (longitude: 10-24, latitude: 45.5-51.5, covered by simulations of CUNI, CHMI, ELU, and OMSZ), and the region in Bulgaria and Romania where the modeled domains of NIMH and NMA overlap (lon.: 21-28.5, lat.: 43-45.5). The results for each simulation were first interpolated to a common regular grid and then averaged separately for ALADIN and RegCM models giving two sets of results referred to as Aladin set and RegCM set. No weighting of models was applied for the calculation of averages. All of the analyses were carried out using only those grid points from the inner modeling domains; that is, grid points from the boundary zone were discarded first.

For both $2 \mathrm{~m}$ temperature and precipitation, we show first overall change of the respective variable between control period and future periods as the difference in 30-year averages over the common area. Changes in the seasonal average values are discussed in more detail showing the correspondence between high resolution regional models and their driving fields. Results of CECILIA models are compared with the simulations of ICTP and CNRM that were used as driving fields for CECILIA simulations along with the average of 14 model runs from the ENSEMBLES project as a reference [26]. From the total number of 25 ENSEMBLES regional simulations, only those that were available for both near and far future periods were used for comparison.

Seasonal values were calculated as country averages. Five countries were picked, Czech Republic, Slovakia, Hungary, Romania, and Bulgaria, for which the values were computed by averaging values in the grid points covered by the respective country area. Regions of Slovakia and Hungary were covered by five modeling groups (CHMI, CUNI, ELU, OMSZ, and NMA); Czech Republic was covered by four groups (CHMI, CUNI, ELU, and OMSZ). Countries from the Eastern European part of the area, Romania and Bulgaria, were each included only in the modeling domain of their respective WP2 partner, NMA and NIMH.

3.1. Climate Response for $2 \mathrm{~m}$ Temperature. Annual $2 \mathrm{~m}$ temperature changes as represented in scenario runs of CECILA models are shown in Figure 2. Both Aladin and RegCM set of the models agree in the basic features: warming up to $3^{\circ} \mathrm{C}$ in near future and between +2 and $+5^{\circ} \mathrm{C}$ in far future. The spatial pattern of the changes is consistent with warming values increasing in the southeastern direction. In general, the warming is stronger in Aladin model set in all domain parts. 


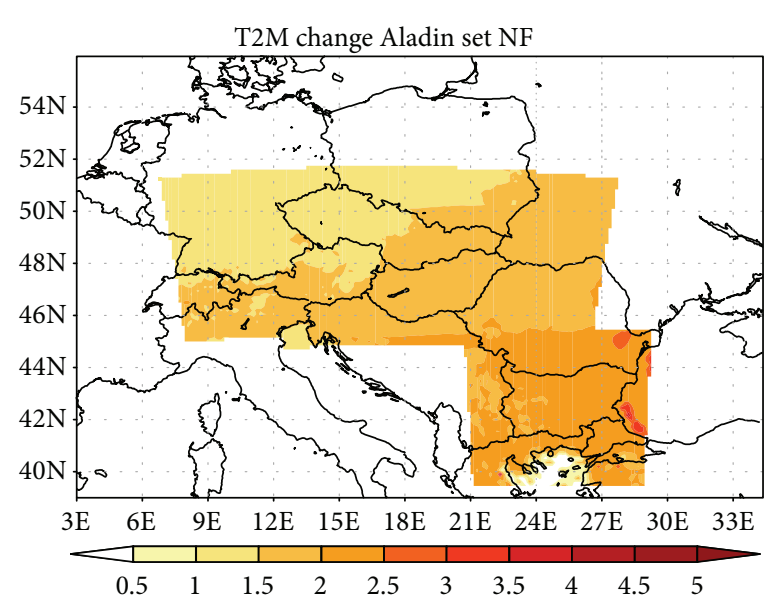

(a)

T2M change Aladin set FF

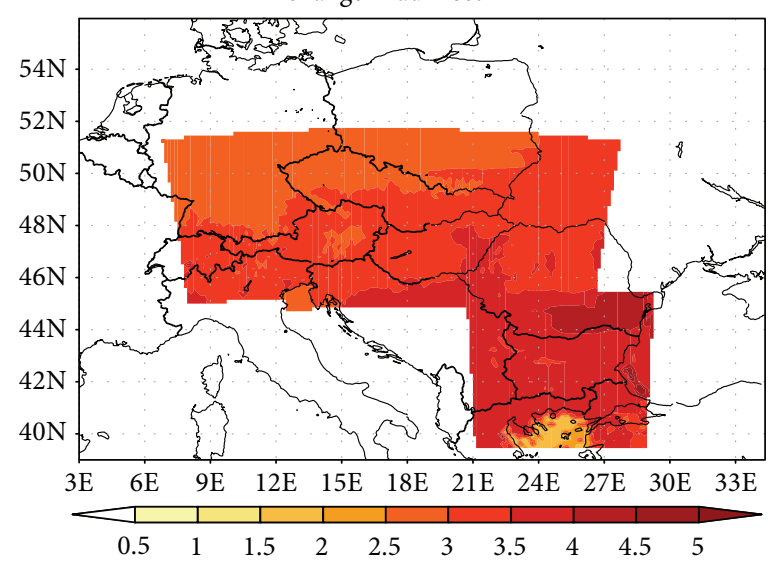

(c)
T2M change RegCM set NF

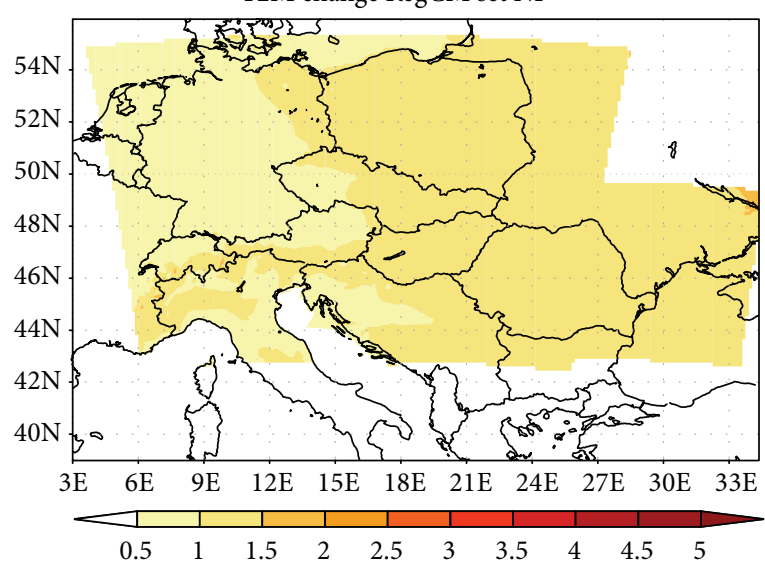

(b)

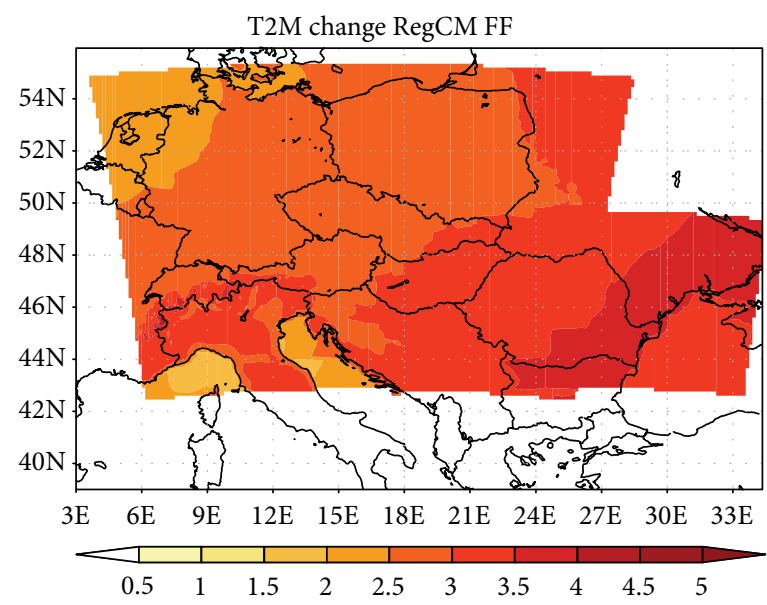

(d)

Figure 2: Change in annual $2 \mathrm{~m}$ temperature in Aladin (a, c) and RegCM (b, d) set between 2021-2050 and 1961-1990 (a, b) and 2071-2100 and 1961-1990 (c, d). Units are ${ }^{\circ} \mathrm{C}$.

Changes of seasonal $2 \mathrm{~m}$ temperature in near future lie within the range between 0 and $+3^{\circ} \mathrm{C}$ (Figures 3, 4, 5, 6, and 7, left). Aladin models give higher rise in temperature than RegCM models in summer and fall season. In winter and spring, there is small difference between model sets. In all analysed countries, RegCM models usually preserve the interseasonal structure of their driving fields with the highest values in spring and winter and the smallest in summer. In autumn, the response is weaker in RegCM models, while the driving ICTP model gives the strongest response. Aladin models agree with the warming present in their driving Arpege model except for summer when the response in the high resolution Aladin is stronger over Hungary, Slovakia, and Bulgaria.

In the far future time slice (Figures 3-7, right), this behaviour is even more pronounced. Warming present in the high resolution RegCM models is very similar to the response in their driving ICTP model with the values between +2.5 and $+3.5^{\circ} \mathrm{C}$. For countries in the northern part of the domain (Czech Rep. and Slovakia), the temperature increase is the highest in winter; in southern countries (Hungary, Romania), the highest increase occurs in summer season. Aladin models tend to give higher increase in temperature than the global Arpege model in all seasons except winter. In winter, Aladin models show lower response than RegCM models.

While the models generally agree on the spatial structure of mean changes, there is quite significant difference in the representation of changes in interannual variability, shown in Figure 8 as interannual standard deviation of seasonal temperature. During summer months, there is a consistent signal of increased variability in all parts of the domain. Other seasons exhibit much larger spread between model sets and time slice. RegCM models tend to prefer bipolar structure with increased variability in the southern part and decreased (or not changed) variability in the northern part of the domain. 


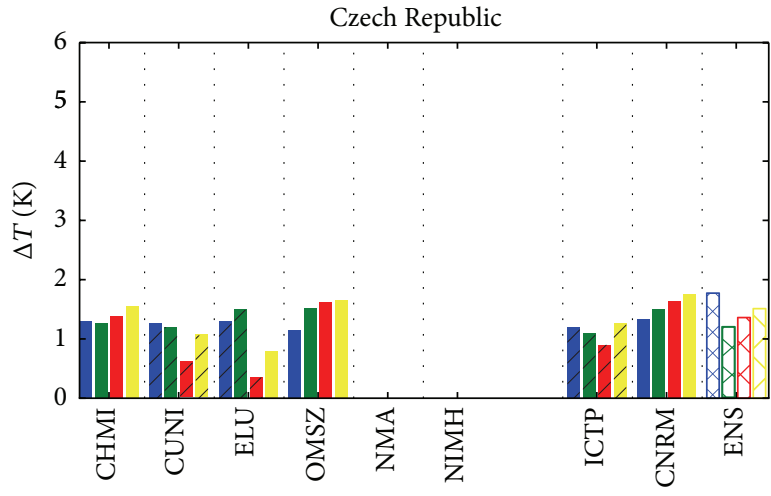

(a)

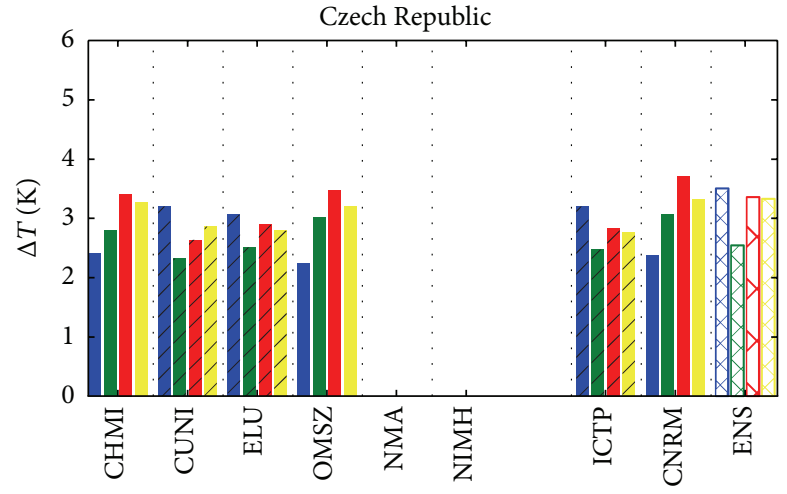

(b)

Figure 3: Change in $2 \mathrm{~m}$ temperature over Czech Republic between 2021-2050 and 1961-1990 (a) and 2071-2100 and 1961-1990 (b); blue = DJF, green $=$ MAM, red $=$ JJA, yellow $=$ SON, hatched $=$ RegCM-ECHAM couple, plain $=$ Aladin-Arpege couple, and ENS $=$ average of 14 ENSEMBLES models.

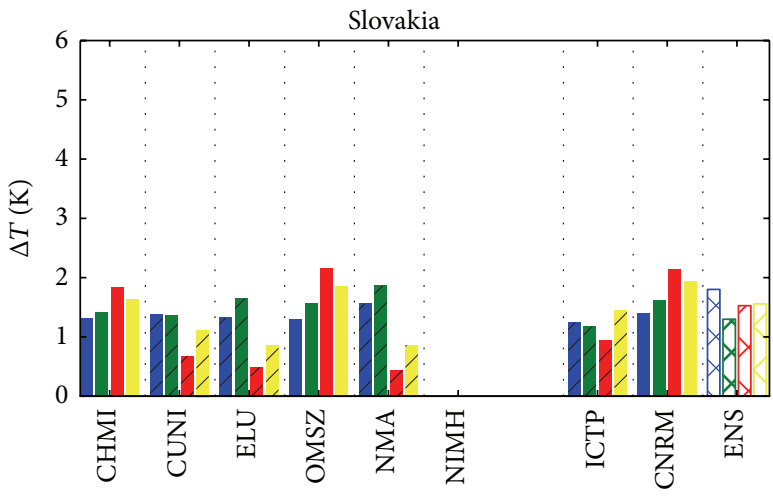

(a)

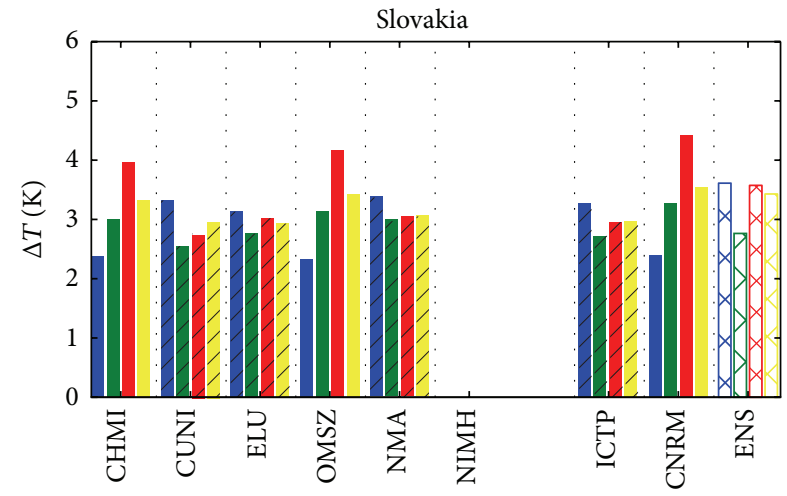

(b)

FIgURE 4: As Figure 3 for Slovakia.

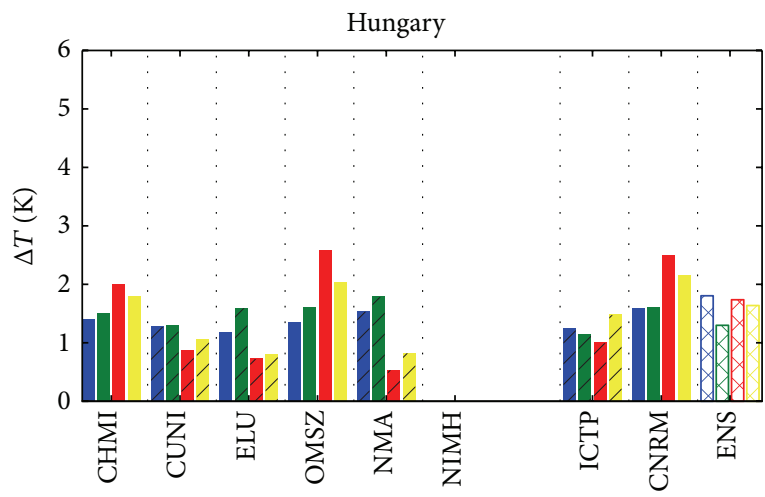

(a)

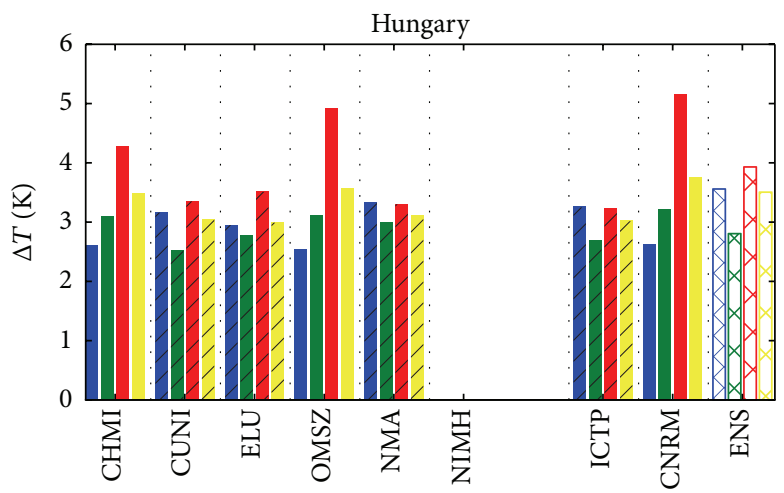

(b)

Figure 5: As Figure 3 for Hungary. 


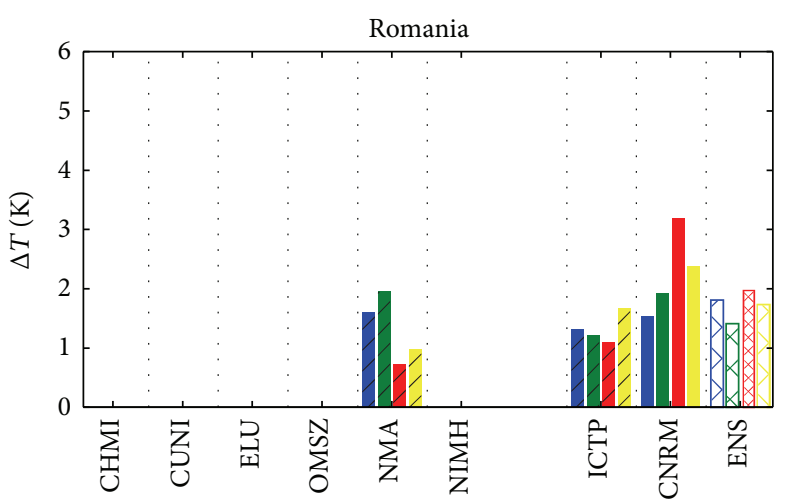

(a)

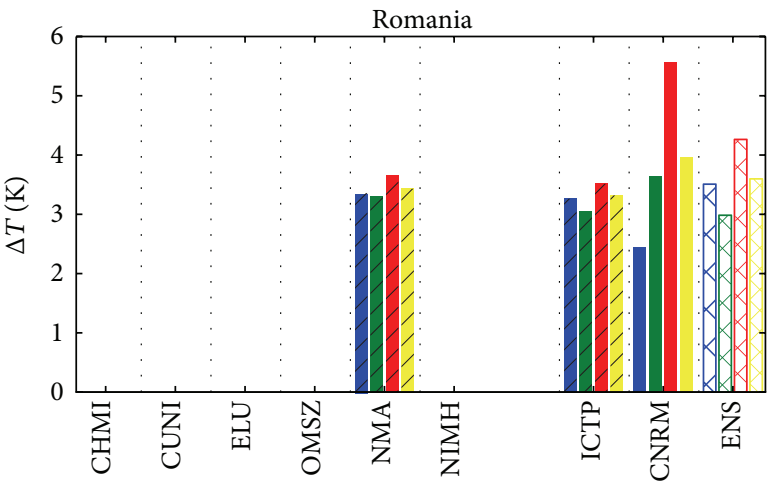

(b)

Figure 6: As Figure 3 for Romania.

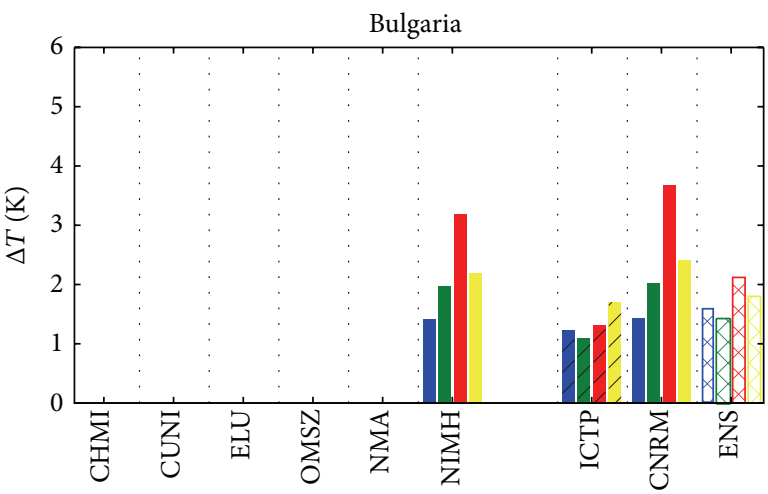

(a)

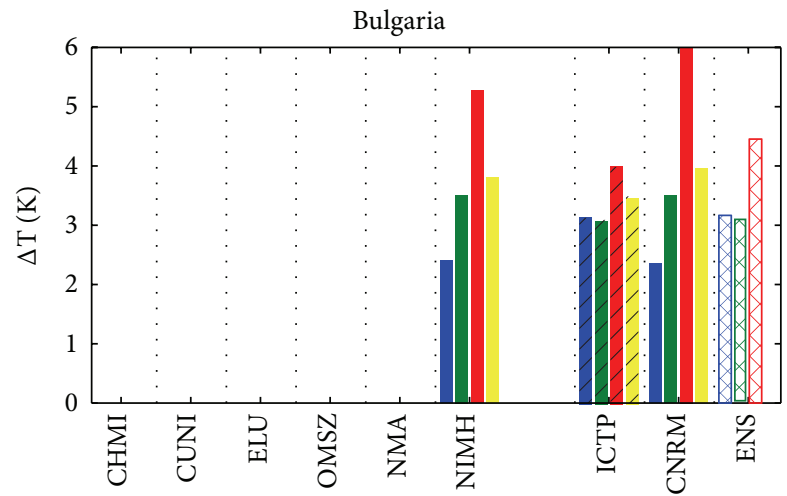

(b)

Figure 7: As Figure 3 for Bulgaria.

3.2. Climate Response for Precipitation. Changes in precipitation are more varied between models and integration domains. Overall pattern of total precipitation (Figure 9) present in both model sets is that of small changes (between -0.25 and $+0.25 \mathrm{~mm} /$ day) with significant decrease in mountainous areas (RegCM) and near domain borders (Aladin) where the modelled precipitation exhibits large biases.

During individual seasons, RegCM models generally copy the patterns present in the driving ICTP simulation. This pattern is characterised by small increase in precipitation (up to $0.3 \mathrm{~mm}$ /day) in winter, summer, and autumn and decrease (up to $-0.3 \mathrm{~mm} /$ day) in spring in the near future time slice (Figures 10,11,12,13, and 14, left). Over Hungary and Slovakia, the ELU simulation changes the sign of the response, giving small decrease in winter and autumn (around $-0.2 \mathrm{~mm} /$ day). In near future, Aladin simulations mostly decrease precipitation in winter with values ranging from $-0.1 \mathrm{~mm} /$ day to $-0.3 \mathrm{~mm} /$ day and increase precipitation up to $0.25 \mathrm{~mm} /$ day in other seasons. The exceptions are OMSZ simulation over Hungary which decreases precipitation in summer and Bulgaria where NIMH simulation gives decrease in all seasons except autumn.
For the late 21st century period (Figures 10-14, right), the response is generally higher in absolute values. All RegCM models agree on increasing precipitation in winter and autumn $(0.15-0.76 \mathrm{~mm} /$ day $)$ and decreasing it in summer (up to $-0.45 \mathrm{~mm} /$ day) with the exception of ELU simulation showing almost no change in autumn over Slovakia and NMA simulation that gives slight increase in summer over Hungary. Spring precipitation is increased over Czech Republic, decreased over Hungary, decreased over Slovakia by ELU and NMA simulations, and increased by CUNI simulation. Aladin models are consistently decreasing precipitation in summer (up to $-0.84 \mathrm{~mm} /$ day) and slightly in winter (up to $-0.1 \mathrm{~mm} /$ day). In spring, the precipitation is increased over Czech Republic, Slovakia, and Hungary and decreased over Bulgaria. Autumn precipitation is mostly slightly decreased except for Hungary and Czech Republic.

As a measure of interannual variability for precipitation, coefficient of variation was adopted after [27]. Figure 15 shows changes of variability in seasons. The signal is not very strong; only in summer and autumn season a tendency towards higher variability in eastern part of the domain can be identified. The highest increase, though, is again present 

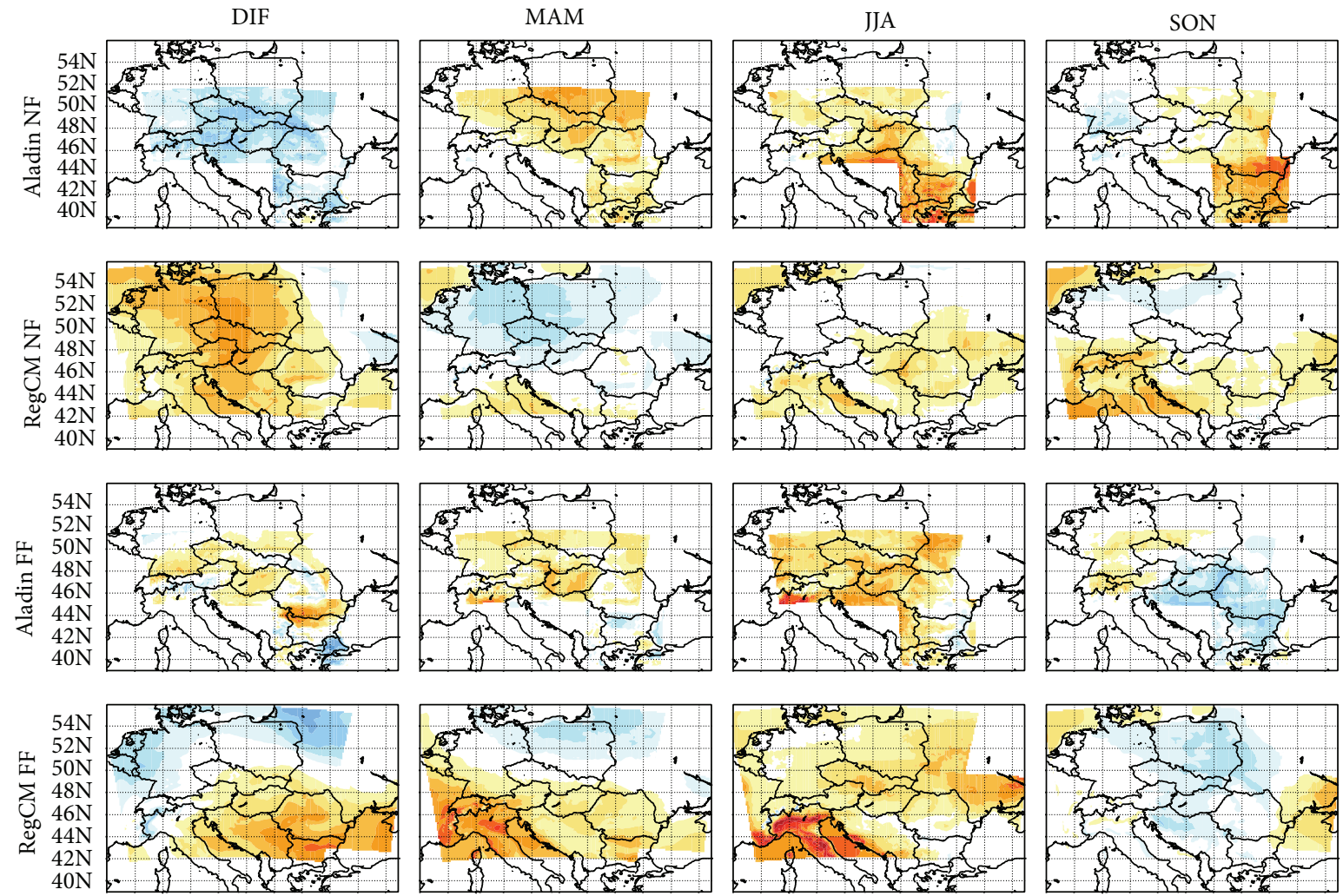

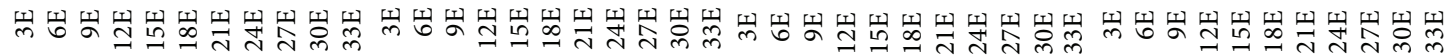

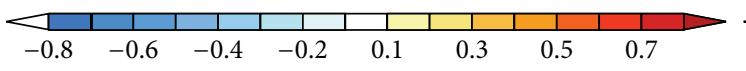

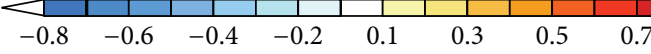

FIGURE 8: Change in $2 \mathrm{~m}$ temperature interannual standard deviation. Units are ${ }^{\circ} \mathrm{C}$.

in the border parts of the domain, which may indicate a nonphysical cause of such behaviour.

From previous analyses (e.g., [14]), the RegCM alpha simulations forced by ERA40 are known to have large bias in precipitation (up to $200 \%$ in some cases). The same situation occurs in case of ECHAM forced runs and is evident from Figures 16, 17, and 18. Precipitation simulated from the RegCM model set is systematically higher by around $+0.5 \mathrm{~mm} /$ day in the Central European part of the domain where CUNI simulations made with the alpha version of RegCM model are present. In the southeastern area, where only RegCM beta simulations of NMA are available, there is only small difference between Aladin and RegCM results. This fact raises a question of reliability of the future period simulations performed by RegCM alpha model. Strictly speaking, poor performance of the model in the "perfectboundary" conditions renders the results of GCM-forced simulation less credible. However, we argue that, considering the consistency of future response between alpha and beta version, the results of RegCM alpha are applicable for climate change assessment and after applying proper statistical processing methods even for impact studies.

\section{Summary and Conclusions}

In this paper, we presented basic properties of climate change scenarios downscaled by high resolution regional climate models for the area of Central and Eastern Europe under the IPCC A1B scenario. Regional models used were RegCM3 and ALADIN-Climate forced by lateral boundary conditions from global models ECHAM and ARPEGE-CLIMAT, respectively. Periods simulated were 2021-2050 (near future) and 2071-2100 (far future) with the reference period 1961-1990. Climate response for $2 \mathrm{~m}$ temperature and precipitation was analysed in terms of annual and seasonal mean change and interannual variability.

Both models show the same general features: warming between 0 and $3^{\circ} \mathrm{C}$ in near future and 2 and $5^{\circ} \mathrm{C}$ in far future with least warming in the northwestern part of the domain increasing towards the southeast. The seasonal values are more varied between model sets, with RegCM3 having more consistent results with its forcing model. This behaviour is persistent in all analyses and can be partly attributed to the fact that ALADIN-Climate uses boundary conditions directly from global ARPEGE-CLIMAT with horizontal resolution of $50 \mathrm{~km}$. On the other hand, RegCM3 model is used 


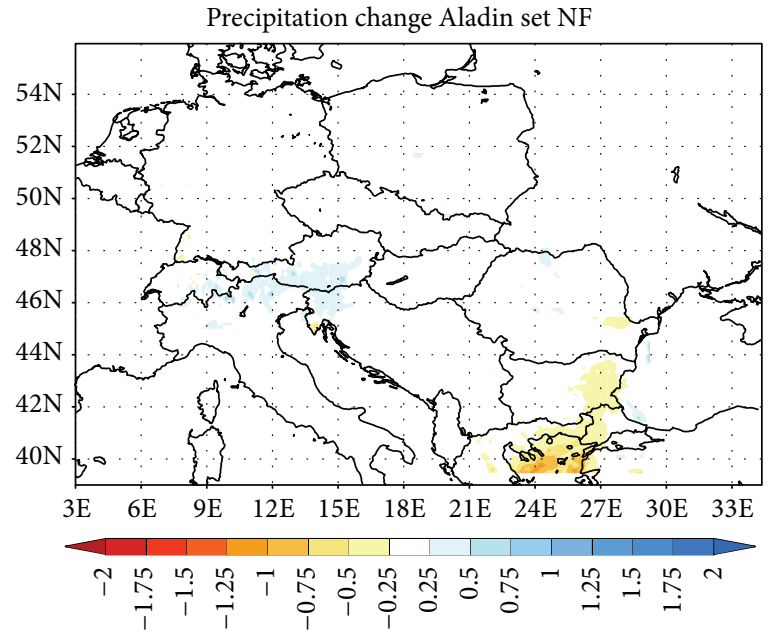

(a)

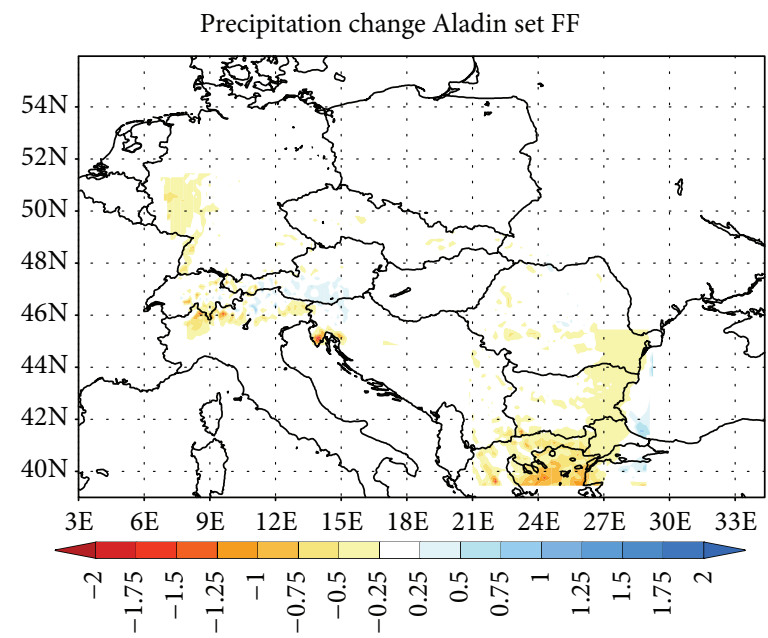

(c)

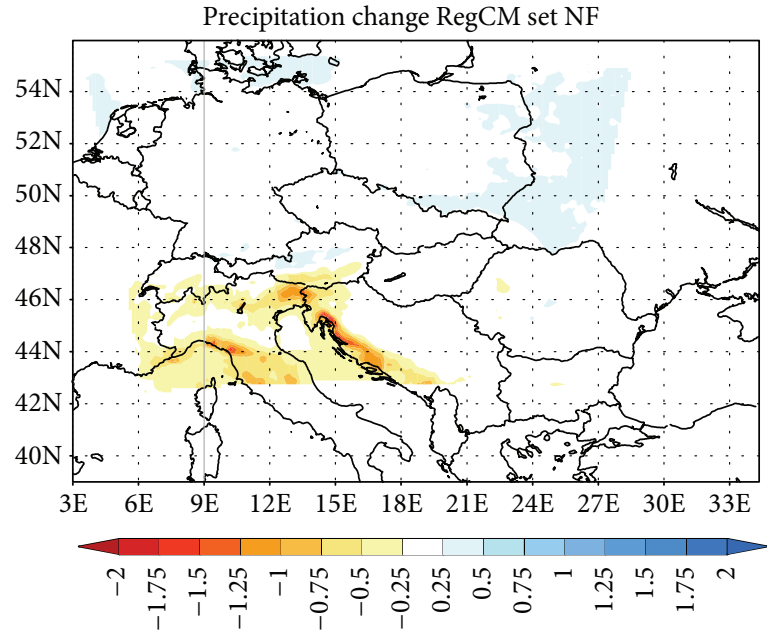

(b)

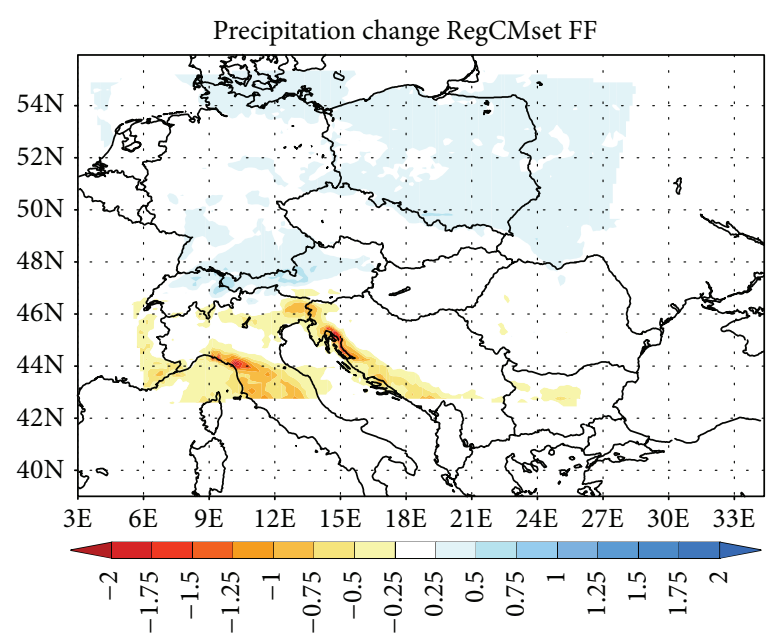

(d)

Figure 9: Change in total precipitation in Aladin (a, c) and RegCM (b, d) set between 2021-2050 and 1961-1990 (a, b) and 2071-2100 and 1961-1990 (c, d). Units are mm/day.

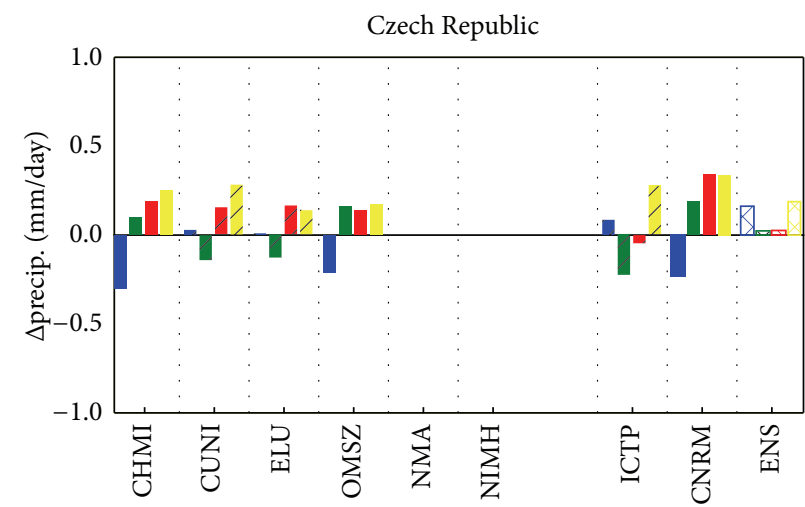

(a)

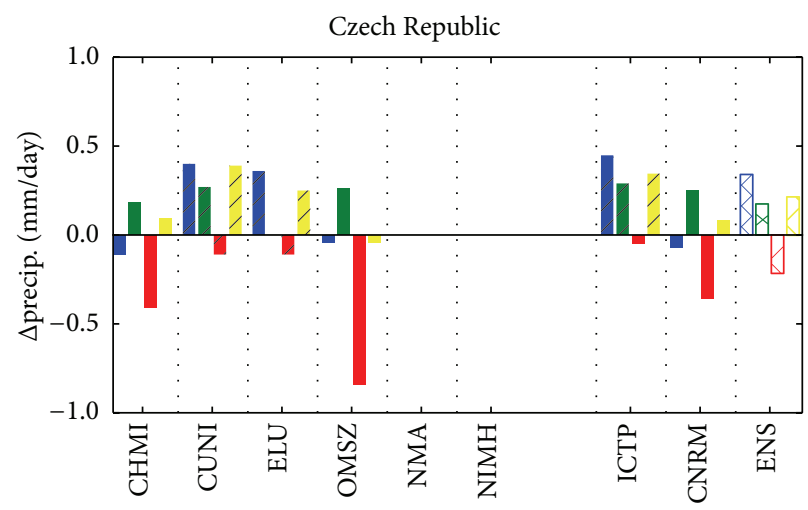

(b)

Figure 10: Change in total precipitation over Czech Republic between 2021-2050 and 1961-1990 (a) and 2071-2100 and 1961-1990 (b); blue $=\mathrm{DJF}$, green = MAM, red = JJA, yellow $=$ SON, hatched = RegCM-ECHAM couple, plain = Aladin-Arpege couple, and ENS $=$ average of 14 ENSEMBLES models. 


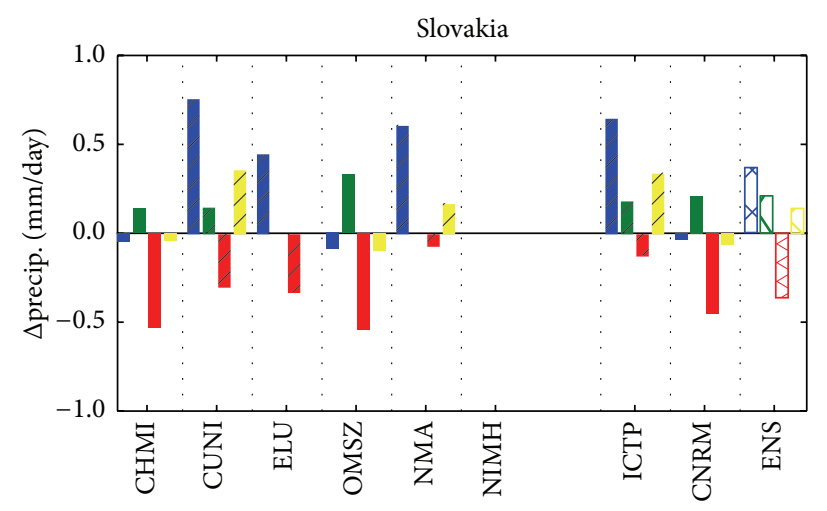

(a)

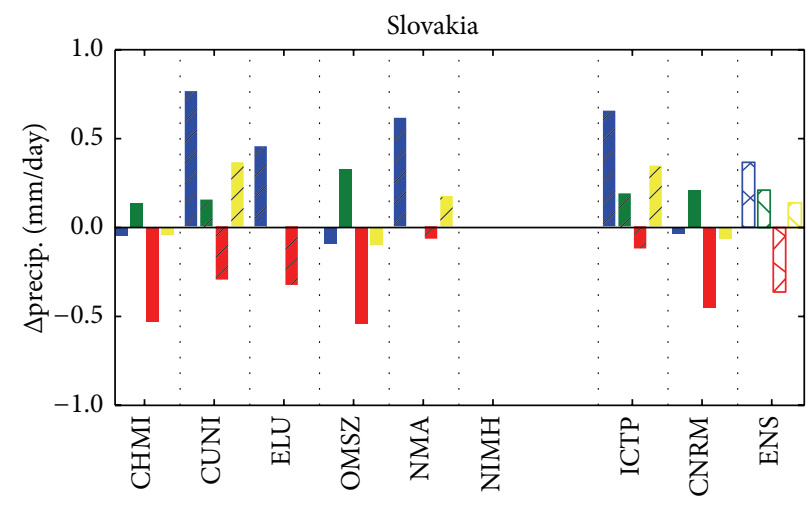

(b)

FIgURE 11: As Figure 10 for Slovakia.

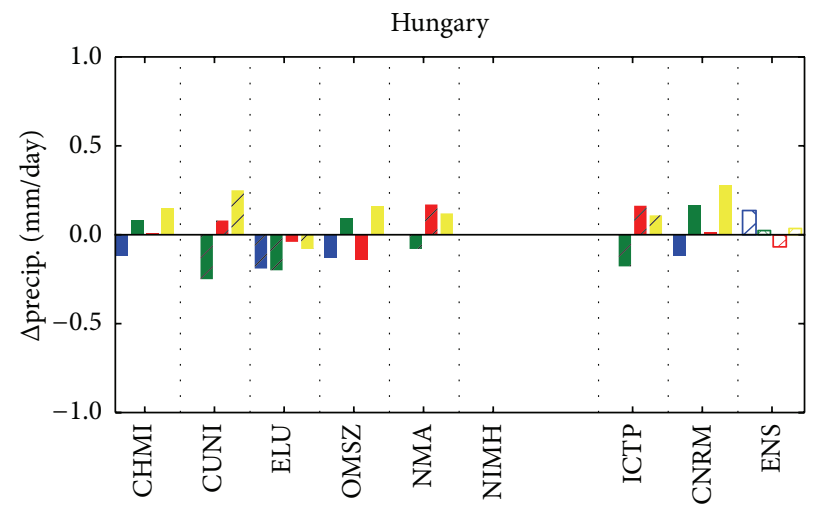

(a)

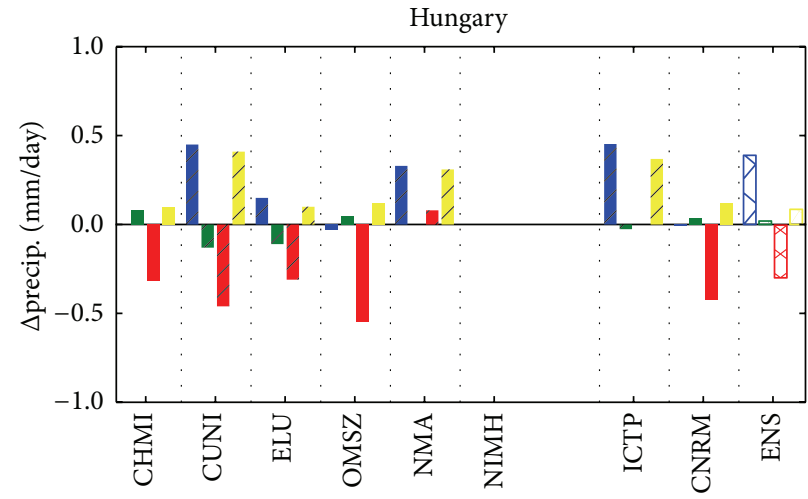

(b)

FIgURE 12: As Figure 10 for Hungary.

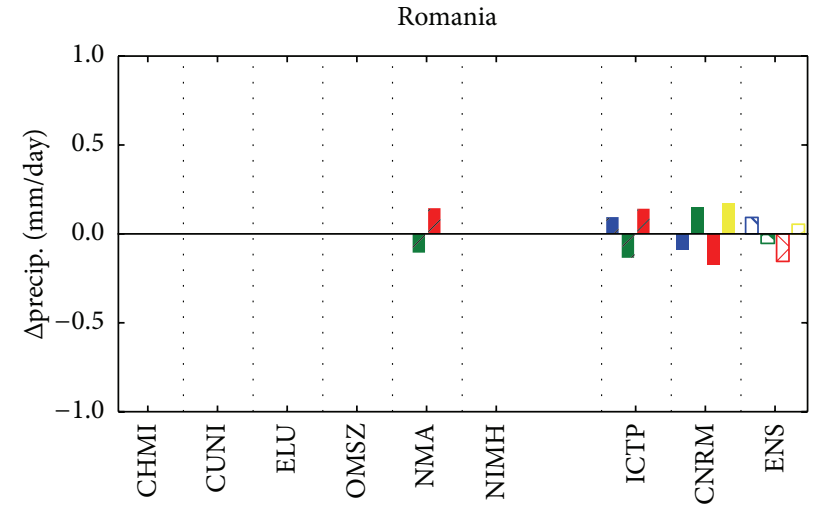

(a)

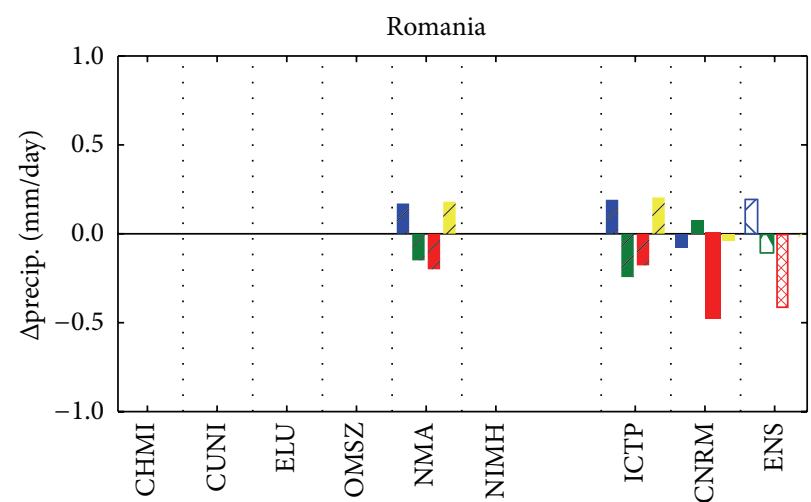

(b)

Figure 13: As Figure 10 for Romania.

in double-nested mode, taking boundary conditions from $25 \mathrm{~km}$ RegCM3 simulation forced by global ECHAM model.

Precipitation is projected to undergo very small changes in the first half of the century. The response is larger for the end of the century with values within the range +1 to $-1 \mathrm{~mm} /$ day. The signal is also very consistent in the high resolution simulations with the models used for driving; generally, the RegCM model family show more consistency, while 


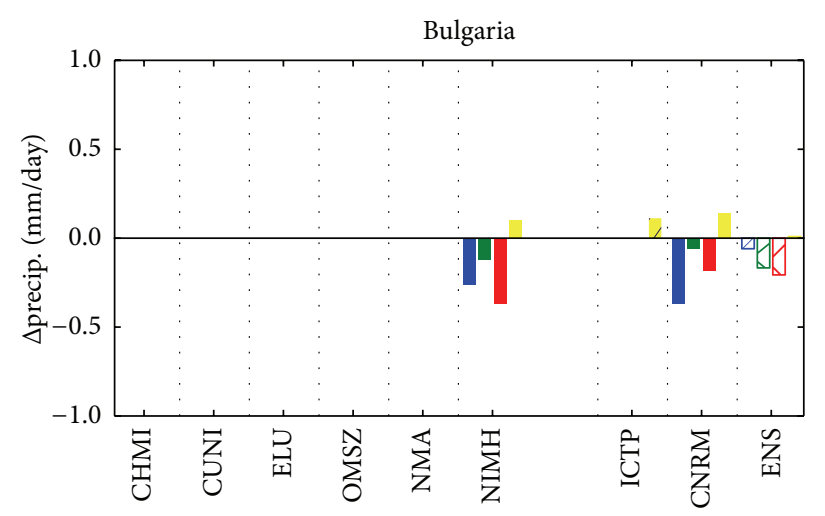

(a)

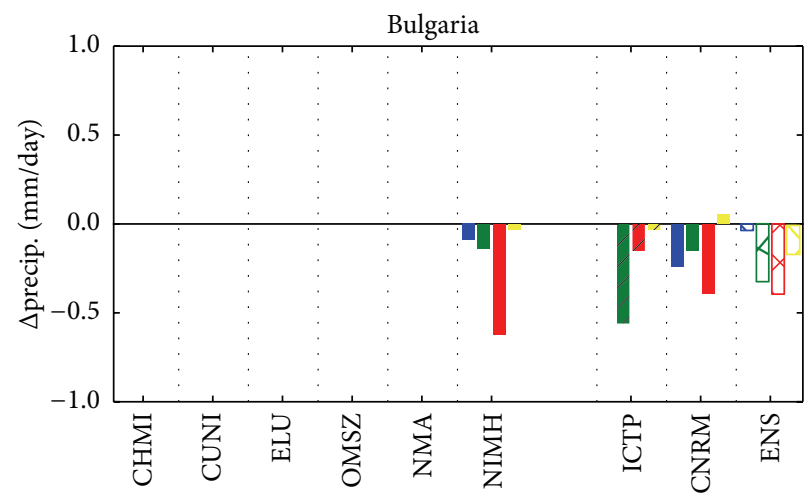

(b)

FIgURe 14: As Figure 10 for Bulgaria.
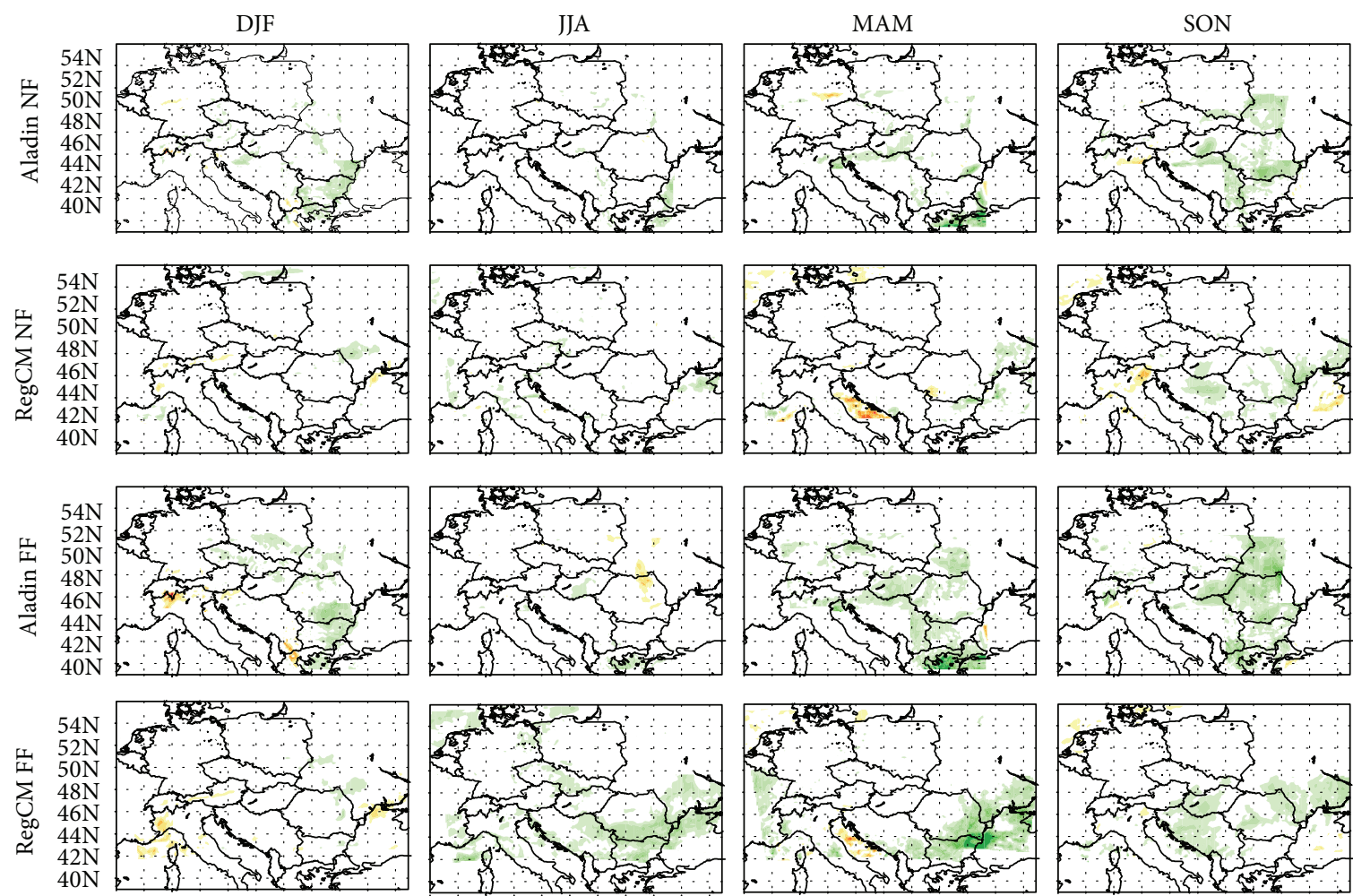

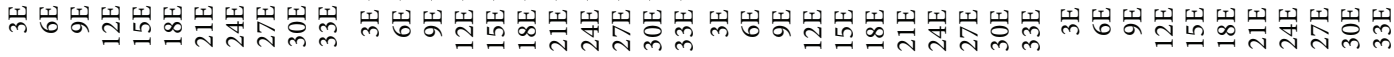
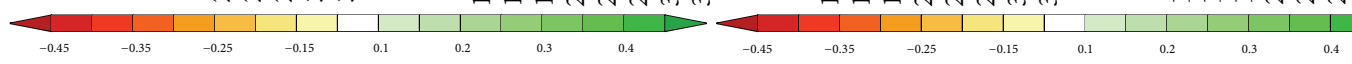

FIGURE 15: Change in precipitation interannual coefficient of variation. Units are percent.

Aladin family in some cases alter not only the magnitude of the change but also the sign.

The climate change signal present in the CECILIA simulations is comparable to previous regional-scale projections carried out within projects such as PRUDENCE or ENSEMBLES (see, e.g., $[5,28])$. The high resolution models focusing on specific regions are capable of retaining the same large-scale patterns that are found in their lower resolution counterparts, while adding some local features that cannot be identified in the driving fields. Interestingly, this added information is not confined only to regions with major orographic features but is consistent across the whole domain of interest.

The results analysed in this paper show that the modeling system employed within the CECILIA project is capable of delivering regionalized climate information beyond simple interpolation of GCM outputs. Even though the models exhibit nonnegligible biases [14], the simulations carried out 


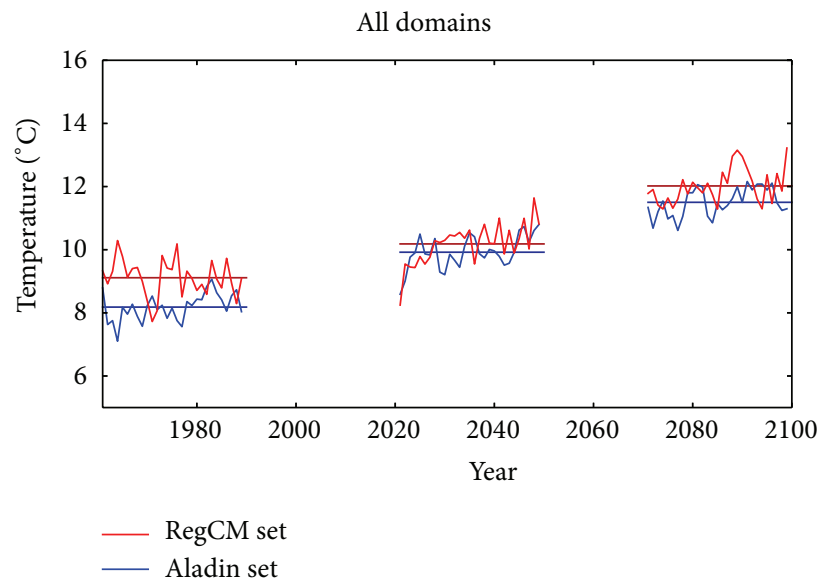

(a)

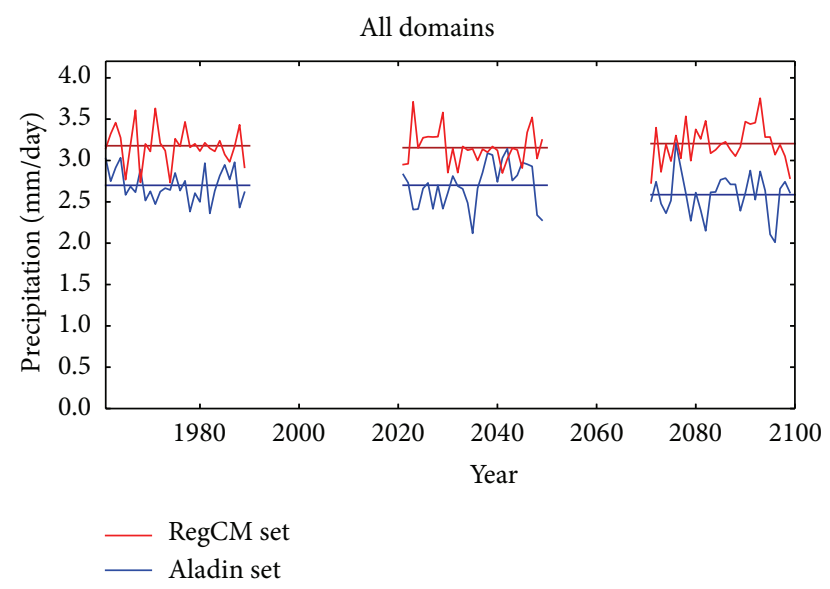

(b)

FIGURE 16: Average $2 \mathrm{~m}$ temperature (a) and precipitation (b) over common CECILIA domain; annual average (thin line) and 30-year average (thick line).

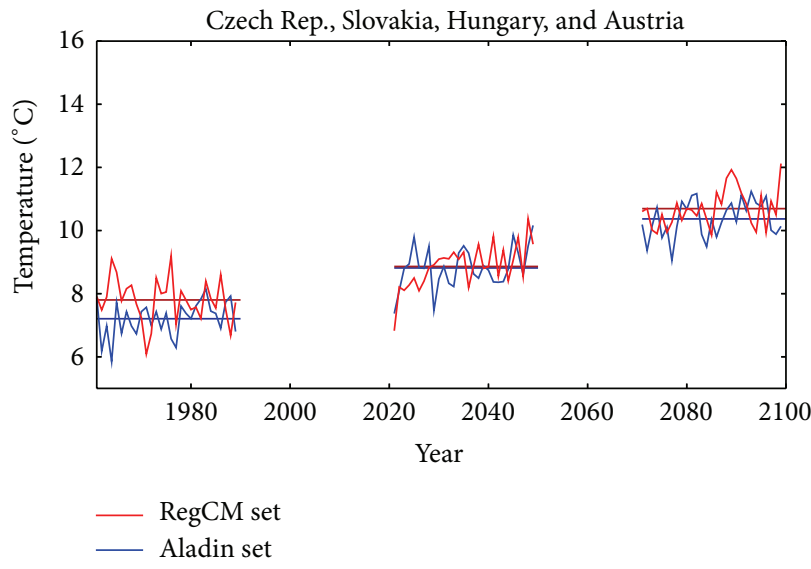

(a)

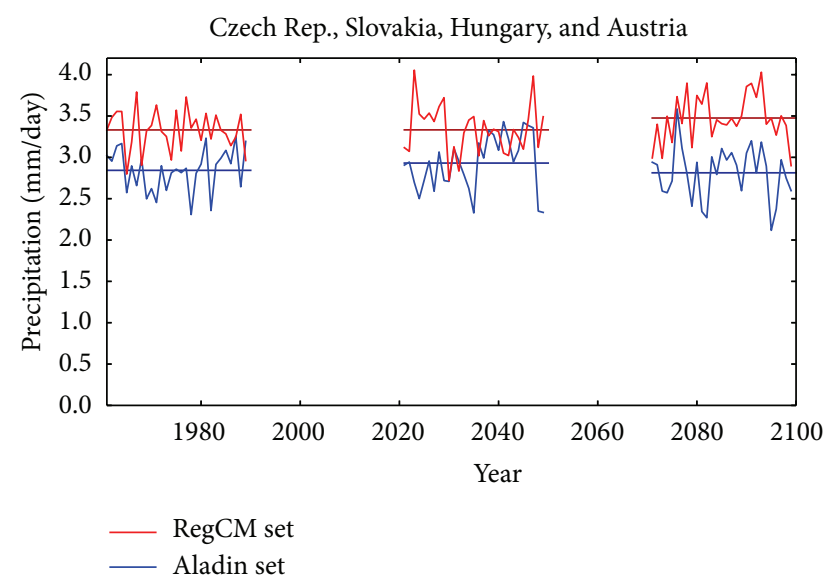

(b)

Figure 17: Average $2 \mathrm{~m}$ temperature (a) and precipitation (b) over Central Europe; annual average (thin line) and 30-year average (thick line).

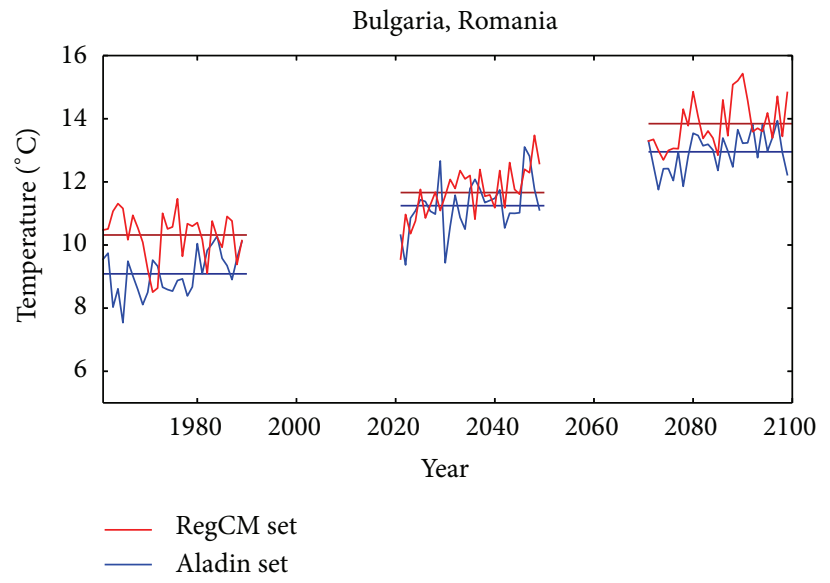

(a)

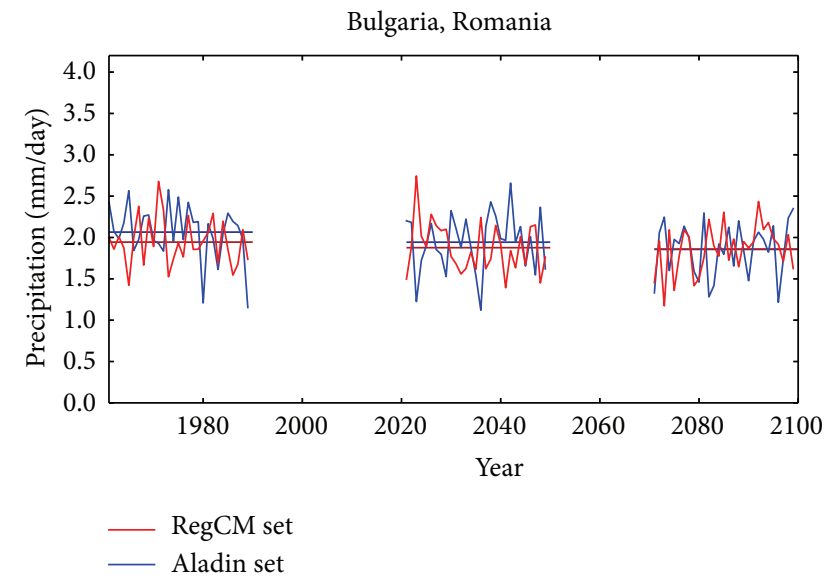

(b)

Figure 18: Average $2 \mathrm{~m}$ temperature (a) and precipitation (b) over common area of Bulgaria and Romania; annual average (thin line) and 30-year average (thick line). 
provide good basis for further model development and use in climate change assessment.

\section{Conflict of Interests}

The authors declare that there is no conflict of interests regarding the publication of this paper.

\section{Acknowledgments}

This study was performed within the CECILIA project, funded by European Commission's 6th Framework Programme under Contract no. 037013. The authors also gratefully acknowledge the financial support of the following foundations and research programs: CzechGlobe Centre (CZ.1.05/1.1.00/02.0073) and projects CZ.1.07/2.3.00/20.0248 (Operational Programme of Education for Competitiveness of Ministry of Education, Youth and Sports of the Czech Republic) and P209/11/2405 (Czech Science Foundation). The authors also acknowledge the ENSEMBLES project, funded by European Commission's 6th Framework Programme through Contract GOCE-CT-2003-505539.

\section{References}

[1] F. Giorgi and L. O. Mearns, "Approaches to the simulation of regional climate change: a review," Reviews of Geophysics, vol. 29, no. 2, pp. 191-216, 1991.

[2] F. Giorgi and L. O. Mearns, "Introduction to special section: regional climate modeling revisited," Journal of Geophysical Research, vol. 104, pp. 6335-6352, 1999.

[3] Intergovernmental Panel on Climate Change, Climate Change 2013: The Physical Science Basis, Cambridge University Press, Cambridge, UK, 2013.

[4] J. H. Christensen, T. R. Carter, M. Rummukainen, and G. Amanatidis, "Evaluating the performance and utility of regional climate models: the PRUDENCE project," Climatic Change, vol. 81, no. 1, pp. 1-6, 2007.

[5] P. van der Linden and J. F. B. Mitchell, Eds., ENSEMBLES: Climate Change and Its Impacts: Summary of Research and Results from the ENSEMBLES Project, Met Office Hadley Centre, London, UK, 2009.

[6] E. Kjellstrom, G. Nikulin, U. Hansson, G. Strandberg, and A. Ullerstig, "21st century changes in the European climate: uncertainties derived from an ensemble of regional climate model simulations," Tellus, Series A: Dynamic Meteorology and Oceanography, vol. 63, no. 1, pp. 24-40, 2011.

[7] E. B. Jaeger and S. I. Seneviratne, "Impact of soil moistureatmosphere coupling on European climate extremes and trends in a regional climate model," Climate Dynamics, vol. 36, no. 910, pp. 1919-1939, 2011.

[8] M. Hirschi, S. I. Seneviratne, V. Alexandrov et al., "Observational evidence for soil-moisture impact on hot extremes in southeastern Europe," Nature Geoscience, vol. 4, no. 1, pp. 17-21, 2011.

[9] T. Halenka, "Regional climate modeling activities in CECILIA project: introduction," Idöjárás, vol. 112, pp. III-IX, 2008.

[10] T. Hlásny, Z. Barcza, M. Fabrika et al., "Climate change impacts on growth and carbon balance of forests in Central Europe," Climate Research, vol. 47, no. 3, pp. 219-236, 2011.
[11] P. Huszar, K. Juda-Rezler, T. Halenka et al., "Effects of climate change on ozone and particulate matter over Central and Eastern Europe," Climate Research, vol. 50, no. 1, pp. 51-68, 2011.

[12] K. Juda-Rezler, M. Reizer, P. Huszar et al., "Modelling the effects of climate change on air quality over Central and Eastern Europe: concept, evaluation and projections," Climate Research, vol. 53, no. 3, pp. 179-203, 2012.

[13] D. Jacob, L. Kotova, P. Lorenz, C. Moseley, and S. Pfeifer, "Regional climate modeling activities in relation to CLAVIER project," Idöjárás, vol. 112, pp. 141-153, 2008.

[14] P. Skalák, M. Déqué, M. Belda et al., “CECILIA regional climate simulations for the present climate: validation and intercomparison," Climate Research, vol. 60, no. 1, pp. 1-12, 2014.

[15] P. Skalák, P. Štěpánek, and A. Farda, "Validation of ALADINClimate/CZ for present climate (1961-1990) over the Czech Republic," Idöjárás, vol. 112, pp. 191-202, 2008.

[16] G. Csima and A. Horányi, "Validation of the ALADIN-Climate regional climate model at the Hungarian Meteorological Service," Idöjárás, vol. 112, pp. 155-178, 2008.

[17] E. B. Jaeger, I. Anders, D. Lüthi, B. Rockel, C. Schär, and S. I. Seneviratne, "Analysis of ERA 40-driven CLM simulations for Europe," Meteorologische Zeitschrift, vol. 17, no. 4, pp. 349-367, 2008.

[18] C. Meissner, G. Schädler, H.-J. Panitz, H. Feldmann, and C. Kottmeier, "High-resolution sensitivity studies with the regional climate model COSMO-CLM," Meteorologische Zeitschrift, vol. 18, no. 5, pp. 543-557, 2009.

[19] S. A. Rauscher, E. Coppola, C. Piani, and F. Giorgi, "Resolution effects on regional climate model simulations of seasonal precipitation over Europe," Climate Dynamics, vol. 35, no. 4, pp. 685-711, 2010.

[20] A. Farda, M. Déué, S. Somot, A. Horányi, V. Spiridonov, and H. Tóth, "Model ALADIN as regional climate model for Central and Eastern Europe," Studia Geophysica et Geodaetica, vol. 54, no. 2, pp. 313-332, 2010

[21] J. S. Pal, F. Giorgi, X. Bi et al., "Regional climate modeling for the developing world: the ICTP RegCM3 and RegCNET," Bulletin of the American Meteorological Society, vol. 88, no. 9, pp. 13951409, 2007.

[22] M. Déqué, "Frequency of precipitation and temperature extremes over France in an anthropogenic scenario: model results and statistical correction according to observed values," Global and Planetary Change, vol. 57, no. 1-2, pp. 16-26, 2007.

[23] C. Torma, J. Bartholy, R. Pongrácz, Z. Barcza, E. Coppola, and F. Giorgi, "Adaptation of the RegCM3 climate model for the Carpathian Basin,” Idöjárás, vol. 112, pp. 233-247, 2008.

[24] C. Torma, E. Coppola, F. Giorgi, J. Bartholy, and R. Pongrácz, "Validation of a high-resolution version of the regional climate model RegCM3 over the Carpathian basin," Journal of Hydrometeorology, vol. 12, no. 1, pp. 84-100, 2011.

[25] N. Nakicenovic, Intergovernmental Panel on Climate Change: Emission Scenarios, a Special Report of Working Group III of the Intergovernmental Panel on Climate Change, Cambridge University Press, Cambridge, UK, 2000.

[26] J. H. Christensen, M. Rummukainen, and G. Lenderink, "Formulation of very-high-resolution regional climate model ensembles for Europe," in ENSEMBLES: Climate Change and its Impacts: Summary of Research and Results from the ENSEMBLES Project, pp. 47-58, Met Office Hadley Centre, Exeter, UK, 2009. 
[27] F. Giorgi, X. Bi, and J. Pal, "Mean, interannual variability and trends in a regional climate change experiment over Europe. II: climate change scenarios (2071-2100)," Climate Dynamics, vol. 23, no. 7-8, pp. 839-858, 2004.

[28] J. Bartholy, R. Pongrácz, G. Gelybó, and P. Szépszó, “Analysis of expected climate change in th e Carpathian Basin using the PRUDENCE results," Idöjárás, vol. 112, pp. 249-264, 2008. 

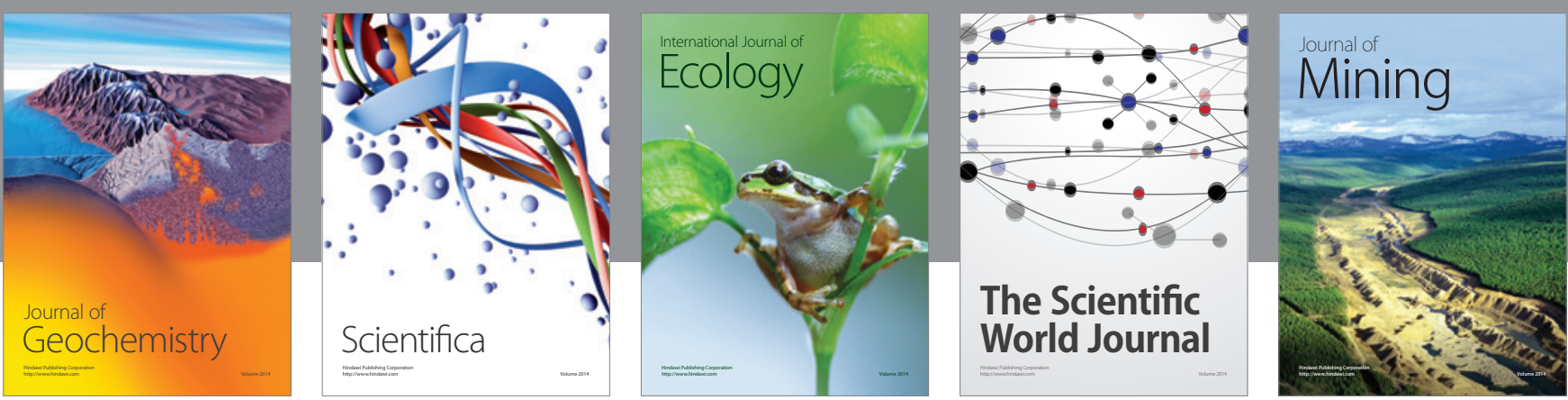

The Scientific World Journal
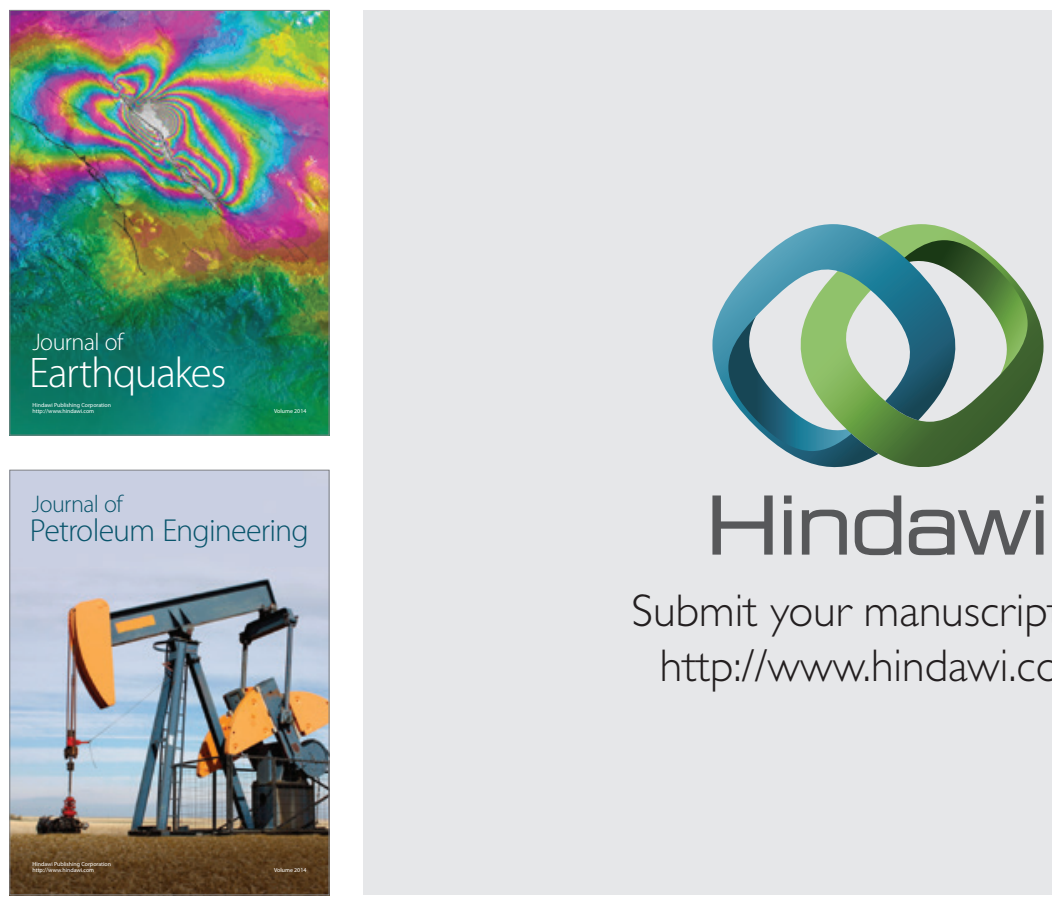

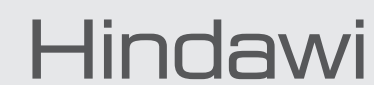

Submit your manuscripts at

http://www.hindawi.com
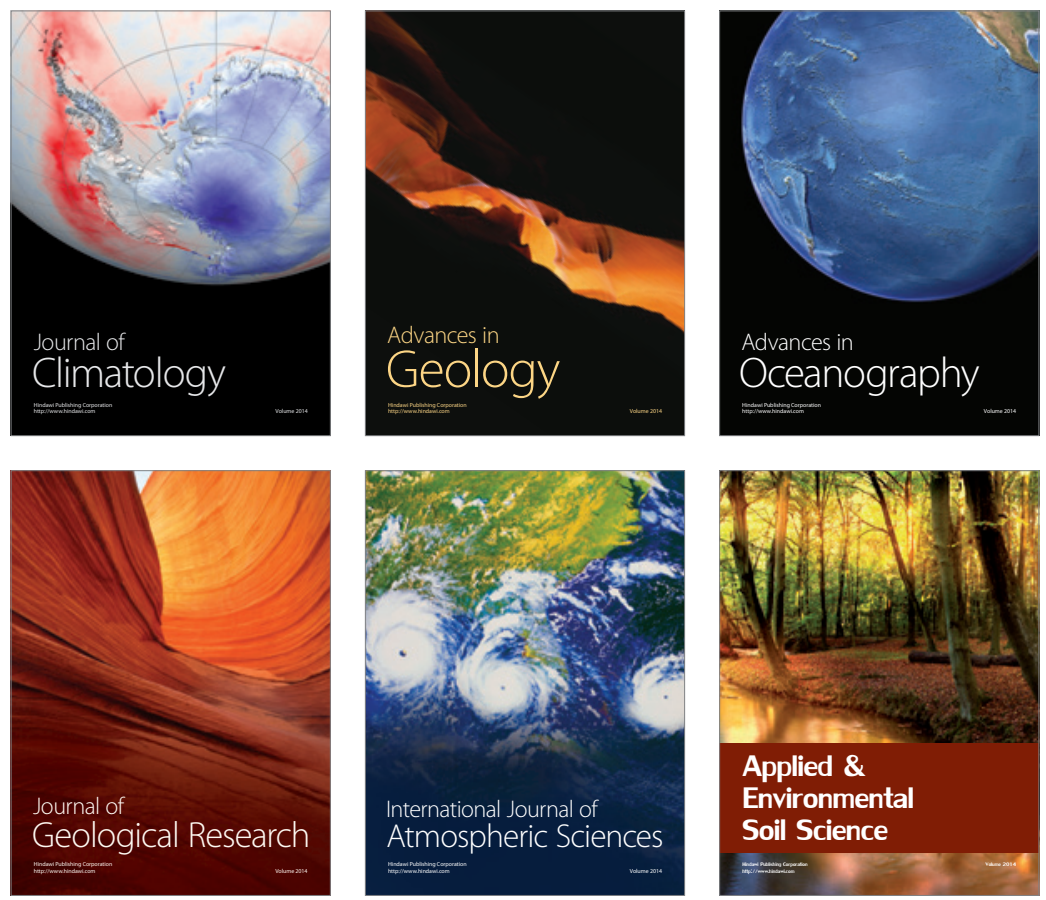
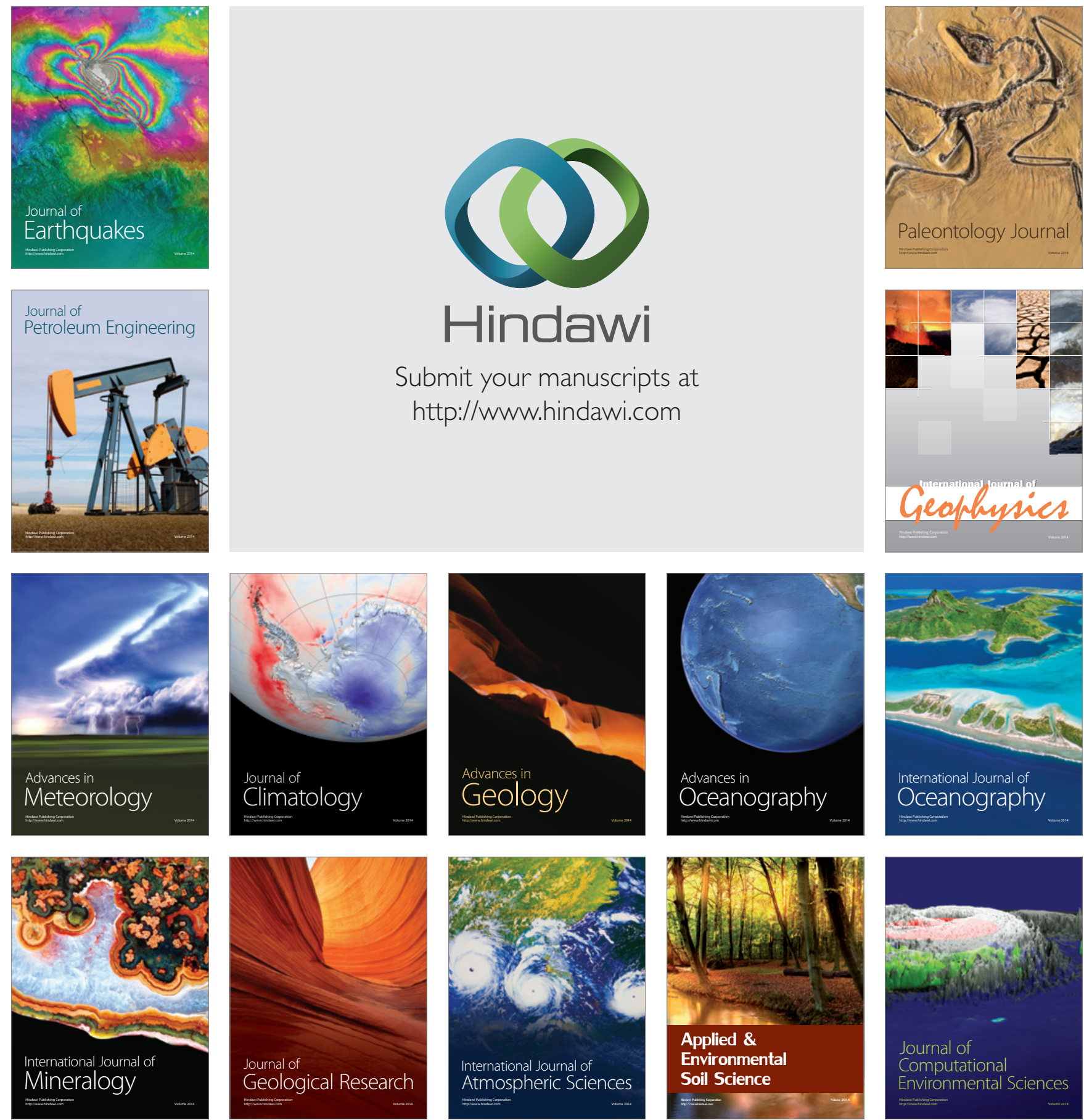